Energy Division

\title{
NAVY MOBILITY FUELS FORECASTING SYSTEM PHASE VI REPORT: \\ IMPACTS OF A MILITARY DISRUPTION ON \\ NAVY FUEL AVAILABILITY AND QUALITY
}

Principal Investigators

G. R. Hadder

R. M. Davis

Published September 1990

Report Prepared for

Navy Energy \& Natural Resources Office

Office of Naval Research

Department of the Navy

Navy Program Manager

A. Roberts

Prepared by the

OAK RIDGE NATIONAL LABORATORY

Oak Ridge, Tennessce 37831

operated by

MARTIN MARIETTA ENERGY SYSTEMS, INC.

for the

U.S. DEPARTMENT OF ENERGY

under Contract No. DE-AC05-84OR21400

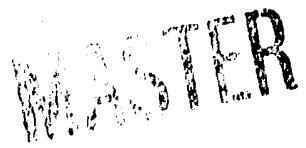


ACRONYMS AND ABBREVIATIONS $\ldots \ldots \ldots \ldots \ldots \ldots \ldots \ldots \ldots \ldots \ldots$ ACKNOWLEDGEMENTS $\ldots \ldots \ldots \ldots \ldots \ldots \ldots \ldots \ldots \ldots \ldots \ldots \ldots$ vii

ABSTRACT $\ldots \ldots \ldots \ldots \ldots \ldots \ldots \ldots \ldots \ldots \ldots \ldots \ldots \ldots \ldots \ldots \ldots$

EXECUTIVE SUMMARY $\ldots \ldots \ldots \ldots \ldots \ldots \ldots \ldots \ldots \ldots \ldots \ldots \ldots \ldots$

1. BACKGROUND FOR MILITARY DISRUPTION ANALYSIS $\ldots \ldots \ldots \ldots \ldots \ldots$

2. MODEL ANALYSIS OF MILITARY DISRUPTION $\ldots \ldots \ldots \ldots \ldots \ldots \ldots \ldots$

3. FUEL PRODUCTION IN U.S. BUREAU OF MINES

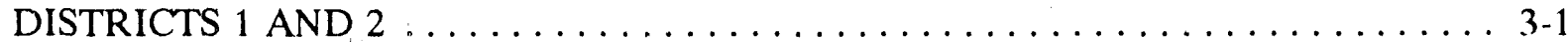

4. FUEL PRODUCTION IN U.S. BUREAU OF MINES

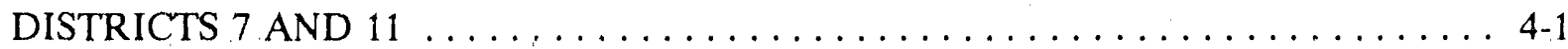

5. FUEL PRODUCTION IN U.S. BUREAU OF MINES DISTRICT $8 \ldots \ldots \ldots \ldots$

6. FUEL PRODUCTION IN U.S. BUREAU OF MINES

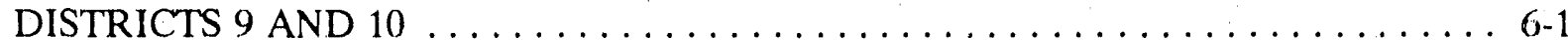

7. FUEL PRODUCTION IN U.S. BUREAU OF MINES DISTRICT $13 \ldots \ldots \ldots \ldots$

8. FUEL PRODUCTION IN THE ASIA REFINING REGION $\ldots \ldots \ldots \ldots \ldots \ldots$.

9. FUEL PRODUCTION IN THE CARIBBEAN REFINING REGION $\ldots \ldots \ldots \ldots . \ldots 9-1$

10. FUEL PRODUCTION IN THE JAPAN REFINING REGION $\ldots \ldots \ldots \ldots \ldots \ldots$. $\ldots$-1

11. FUEL PRODUCTION IN THE NORTH EUROPE REFINING REGION $\ldots \ldots \ldots$ 11-1

12. FUEL PRODUCTION IN THE PACIFIC REFINING REGION $\ldots \ldots \ldots \ldots \ldots$

13. FUEL PRODUCTION IN THE SOUTH EUROPE REFINING REGION . . . . . . 13-1

14. OVERVIEW OF IMPACTS OF MILITARY DISRUPTION $\ldots \ldots \ldots \ldots \ldots \ldots$

15. OBSERVATIONS AND RECCMMENDATIONS $\ldots \ldots \ldots \ldots \ldots \ldots \ldots \ldots \ldots$

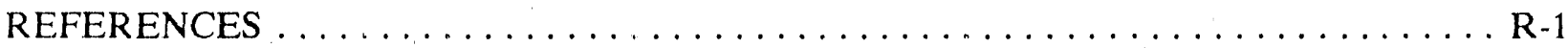

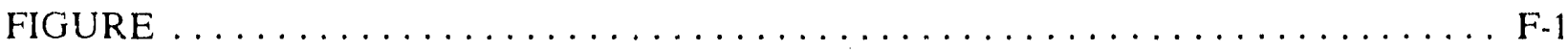

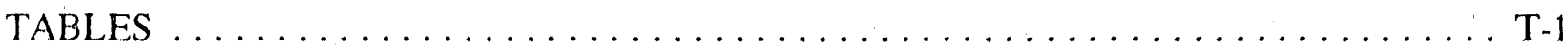




\section{ACRONYMS AND ABBREVIATIONS}

API

$\mathrm{BAU}$

BOM

BTU

DIS

DoD

DOE

EIA

MBD

MMBD

OMS

ORNL

PAL

REMS

RYM
American Petroleum Institute

Business-as-usual

Bureau of Mines

British Thermal Unit

Disruption Impact Simulator

Department of Defense

Department of Energy

Energy Information Administration

Thousand barrels per day

Million barrels per day

Oil Market Simulation

Oak Ridge National Laboratory

Petroleum Allocatior

Refinery Evaluation Modeling System

Refinery Yield Model 


\section{ACKNOWLEDGEMENTS}

Throughout the development and application of the Navy Mobility Fucls Forecasting System, technical guidance and collaboration have been received from the Navy Energy \& Natural Resources Office, the Naval Air Propulsion Center, and the David Taylor Naval Ship Research and Development Center. Insights on petroleum markets and refinery trends have been provided by the East-West Center Resource Systems Institute; Chevron U.S.A., Inc.; Pacific Resources, Inc.; th" Amerada Hess Corporation; the Sun Company; Ashland Petroleum Company; Exxon Company, U.S.A.; Conoco, Inc.; Coastal Corporation; the National Petroleum Council; and the American Petroleum Institute. Technical support, data resources, and access to the principal forecasting models have been furnished by the Energy Information Administration, Department of Energy. EnSys Energy and Systems, Inc., and Turner, Mason and Company have assisted in modification of the refinery models. Temple, Barker \& Sloane, Inc., has provided input on petroleum logistics issues of concern to the Navy. This report was edited and typed by Jonnie Sorensen of Oak Ridge National Laboratory. The valuable contributions of these individuals and organizations are greatly appreciated. 


\begin{abstract}
The Refinery Yield Model of the Navy Mobility Fuels Forecasting System has been used to study the impacts of a severe military disruption on the production of Navy JP-5 jet fuel and F-76 marine diesel fuel in the year 1995. The global petroleum supply reduction due to the disruption was about 40 percent of the business-as-usual supply. Regional production cost increases for JP-5 were between $\$ 3$ and $\$ 11$ per gallon during the disruption. For F-76, the production cost increase sere between $\$ 3$ and $\$ 5$ per gallon. The disruption caused substantial degradations for certain fucl yuality properties of F-76 produced in the Pacific basin and in southern Europe. During both business-asusual and disruption, the most prevalent Navy fuel quality problem was F-76 instability due to high levels of light cycle oils.
\end{abstract}




\section{IMPACTS OF A MILITARY DISRUPTION \\ ON \\ NAVY FUEL AVAILABILITY AND QUALITYY}

\section{EXECUTTVE SUMMARY}

The Navy Mobility Fuels Forecasting System has been used to study the effects of a severe military disruption on the world petroleum supply system, with emphasis on impacts on the availability and quality of Navy mobility fuels.

The disruption occurred during a 90-day period in the year 1995. Conditions of the disruption included total loss of crude oil and refined products from the Persian Gulf, Algeria, and Libya; a 40) percent reduction of crude oil output from the North Sea; an increase of military demand for petroleum to 300 percent of the business-as-usual level; drawdown of the U.S. Strategic Petroleum Reserve at a rate of 4.5 million barrels per day (MMBD); use of Japanese strategic oil stocks at a rate of $0.9 \mathrm{MMBD}$; curtailment of Soviet exports of petroleum and natural gas; a 37 percent reduction of petroleum flows into Europe and a 10 percent reduction of petroleum flows out of Europe; and elimination of 10 percent of petroleum flows in the Asia-Pacific and Indian Occan regions.

The supply reduction due to the disruption was about 40 percent of the business-as-usual supply and created numerous bottlenecks in the petroleum supply system. Certain conditions of the disruption were relaxed to a point of impending bottlenecks, for which petroleum supply could satisfy demand. Otherwise, the forecasting system could not operate in a feasible mode.

The Refinery Yield Model of the forecasting system was used to estimate the impacts of the disruption on the regional refinery production of Navy JP-5 jet fuel and F-76 marine diesel fuel.

The disruption resulted in a five-fold increase in the costs of crude oils, which caused a large increase in the costs of production of all refined petroleum products. Regional production cost increases for JP-5 were between $\$ 3$ and $\$ 11$ per gallon, and F-76 cost increases were between $\$ 3$ and $\$ 5$ per gallon.

During the disruption, refinery utilization was greatly redueed in most regions, providing increased processing flexibility. This flexibility tended to hold down the costs of fuel production.

JP-5 and F-76 produced during the disruption were within specifications in all regions. In a number of cases, Navy fucl properties improved. However, substantial fuel property degradations occurred for F-76 produced in the Pacific basin and in southern Europe.

During both business-as-usual and the disruption, the most prevalent Navy fuel quality problem was F-76 instability due to high levels of light evele oils blended to that fuel. For domestic regions, F-76 was an attractive disposal option for light cycle oil when the aromatics content of civilian highway diesel fuel was limited to 20 maximum volume pereent. These results indicated that 


\section{BACKGROUND FOR MILITARY DISRUPTION ANALYSIS}

Many previous papers and reports ${ }^{1-13}$ have considered the impacts of major disruptions in the supply of oil on the availability and quality of petroleum products. Other studies ${ }^{14-18}$ have discussed oil disruptions, vulnerability, and security, and several modeling approaches have been suggested. ${ }^{6,12,19,20}$

One of the most severe scenarios in past studies was the disruption investigated by Das et al. ${ }^{6}$ In that study, Persian Gulf exports were entirely curtailed, and North Sea production was reduced 40 percent. Military fuel consumption by the U.S. and its allies tripled. In response to the disruption, there was a combined drawdown of 5.9 million barrels per day (MMBD) in civilian and military stocks, mostly from the U.S. Strategic Petroleum Reserve. The net effect was a 16 MMBD reduction in supply.

Nevertheless, the disruption did not seem crippling, either in the sense of military needs going unsatisfied or in terms of the civilian sector requiring rationing or price controls. There was an economic solution to the supply reduction, and equilibrium between supply and demand. In some ways, this finding seemed surprising because the scenario included not just a severe disruption in oil supply, 1 i a large-scale military mobilization as well. To investigate this issue more closely, the Department of Navy, the Department of Energy, and Oak Ridge National Laboratory developed a scenario with a more detailed description of an extreme military-oil market disruption, and investigated the impacts of this scenario on petroleum supply and demand. The global impacts of the scenario are discussed in the companion report by Das et al. ${ }^{21}$ This report describes the impacts of the scenario on regional refining operations, with emphasis on the cost, availability, and quality of Navy JP-5 jet fuel and F-76 marine diesel fucl. 


\section{MODEL ANALYSIS OF MILITARY DISRUPYIION}

The Navy Mobility Fuels Forecasting System has been used to study the effects of a military disruption on Navy fuel availability and quality. The main study objectives were to identify bottlenecks in the world oil supply system during the disruption and to estimate the effects of the disruption on the cost, availability, and quality of the Navy luels JP-5 and F-76.

The forecasting system, shown conceptually in the Figure, consists of four Department of Energy models:

The econometric Oil Market Simulation (OMS) Mode ${ }^{22}$ determines the price at which global supply and demand for oil are in balance. Aggregate supply, demand, and price data from the OMS Model are used for some of the input data requirements of the other models of the forecasting system.

The Disruption Impact Simulator (DIS) is a spreadsheet model which balances global supply and demand for disrupted oil markets.

The Petroleum Allocation (PAL) Mode ${ }^{23}$ is a linear program that estimates global petroleum movements for different market scenarios. Crude oil supplies and the production of relined products are forecast by the PAL Model for input to the Relinery Yield Model.

The Refinery Yicld Model (RYM) is a linear program ${ }^{24,25}$ that represents regional refining operations. The current version of RYM includes 37 refinery processes, which can be used to produce over 30 products from at least 100 crude oils. Most of the RYM petroleum products are described by detailed quality specifications. RYM is executed on a $25 \mathrm{MHz}$ 80386/80387 microcomputer. Haverly Systems Omni and HS/LP software is used to construct and solve the linear program and to produce a report on the solution.

The OMS, DIS, and PAL Models produce an aggregated picture of regional refining under different market seenarios. Although regional refining models are embedded within the PAL Model, they do not explicitly represent the production of important military fucls such as JP-5 and F-76. Therefore, RYM, which contains enhanced descriptions of military fuel production, uses some key results of the PAL Model but is executed independently of the PAL Model. The stand-alene RYM can be used to evaluate many variations of the refining environment. For example, RYM can be used to produce detailed information on the effects of changing refined product prices and specifications.

The OMS, DIS, and PAL Models were used to analyze the global supply implications of a severe military disruption in the year 1995. The conditions of the military disruption included:

Total loss of crude oil and refined product exports from the Persian Gull, Algeria, and Libya during the 9)-day period of the height of military conflict;

A 40 percent reduction of crude oil output from the North Sea; 
An increase of military demand for oil to 300 percent of the business-as-usual (BAU) level;

Drawdown of the U.S. Strategic Petroleum Reserve at a rate of $4.5 \mathrm{MMBD}$;

Use of Japanese strategic petroleum stocks at a rate of $0.9 \mathrm{MMBD}$;

Curtailment of Soviet exports of petroleum and natural gas;

A 37 percent reduction of petroleum flow into Europe and a 10 percent reduction of petroleum flows out of Europe due to military hostilities; and

Elimination of 10 percent of petroleum flows in the Asia-Pacific and Indian Ocean regions, due to military hostilities.

The supply reduction due to the disruption was about 40 percent of the BAU supply and created numerous bottlenecks in the petroleum supply system, as described by Das et al. ${ }^{21}$

The RYM analysis of refinery operations was performed for conditions of impending bottlenecks in the petroleum supply system. Certain conditions of the disruption were relaxed to a point at which petroleum supply could satisfy demand. Otherwise, the forecasting system could not operate in a feasible mode because of true shortages.

RYM was used to analyze refinery operations in all regions, outside the disrupted Persian Gulf, with recent histories of Navy fuel production. The regions were:

U.S. Bureau of Mines (BOM) Districts 1 and 2 (Florida, New York, Pennsylvania, Virginia, West Virginia, Illinois, Indiana, Kansas, Kentucky, Michigan, Missouri, Nebraska, North Dakota, Ohio, Oklahoma, South Dakota, and Tennessee);

BOM Districts 7 and 11 (Inland Texas and New Mexico);

BOM District 8 (Texas Gulf Coast);

BOM Districts 9 and 10 (Louisiana, Mississippi, Alabama, and Arkansas);

BOM District 13 (Alaska, California, Hawaii, Nevada, Oregon, and Washington);

Asia Refining Region (Korea, Taiwan, Philippines, and others);

Caribbean Refining Region (Puerto Rico, Virgin Islands, Bahamas, Netherlands Antilles, and Trinidad);

Japan Refining Region (Japan, including Okinawa);

North Europe Refining Region (Norway, Sweden, Denmark, Finland, Belgium, Netherlands, Luxembourg, United Kingdom, and Ireland); 
Pacific Refining Region (Australia, New Zealand, Indonesia, Singapore, Malaysia, Bahrain, and others); and

South Europe Refining Region (Spain, Portugal, Italy, Greece, and Turkey).

Disruption impacts were estimated by comparing refinery operations during BAU to operations during the disruption. The assumed BAU regional Navy fuel production requirements ${ }^{26,27}$ are shown in Table 1. These production requirements are tripled during the disruption. Because of the stepwise nature of linear programming solutions, the RYM production levels for Navy fucls exceed the target requirements by amounts which provide coverage for lost production in the Persian Gulf region.

Key assumptions for the refinery analysis included the following:

U.S. military forces currently using naphtha jet fuel JP-4 and ground diesel fucl will convert $^{28,29}$ to the use of kerosene jet fuel JP-8.

Domestic motor gasoline will be unleaded and the Reid vapor pressure of summertime motor gasoline $\mathrm{e}^{30}$ will be reduced by about 25 percent relative to the gasoline of the late 1980).

Domestic civilian highway diesel fuel will be restricted to low levels of sulfur (0.05 weight percent) and aromatics (20 volume percent)..$^{31-34}$

Foreign motor gasoline octanes will remain at the levels reported by the National Petroleum Council $^{35}$ in 1986 . Foreign diesel fuel specifications of 1995 will be comparable to current U.S. diesel fuel specifications. 


\section{FUEL PRODUCTION IN U.S. BUREAU OF MINES DISTRICIS 1 AND 2 (Florida, Ncw York, Pennsylvania, Virginia, West Virginia, Illinois, Indiana, Kansas, Kentucky, Michigan, Missouri, Nebraska, North Dakota, Ohio, Oklahoma, South Dakota, and Tennessec)}

The assumed 1995 BAU production requirement for F-76 in BOMs 1 \& 2 is 0.3 thousand barrels per day (MBD), and the military disruption requirement for F-76 is $0.9 \mathrm{MBD}$. The estimated increase in the cost of F-76 due to the disruption is $\$ 2.70$ per gallon (1995 U.S. dollars). As shown in Table 2, of all the domestic regions, the cost increase is the lowest, due in part to greater processing flexibility during the disruption. For example:

Utilization of crude distillation capacity drops 52 percent; and

Utilization of distillate desulfurization capacity drops 41 percent. following:

Table 3 summarizes the impacts of the disruption on the quality of F-76, including the

Aromatics content increases moderatsly; and

Pour point decreases (improves) substantially.

Because of high percentages of light cycle oils used to produce F-76 during both BAU ( 46.5 percent) and disruption ( 45.5 percent), these fuels could have stability problems, with tendencies to produce gums and other particulates. 


\section{FUEL PRODUCTION IN U.S. BUREAU OF MINES DISTRICTS 7 AND 11 (Inland Texas and New Mexico)}

The assumed BAU production requirement for JP-5 in BOMs $7 \& 11$ is $1.1 \mathrm{MBD}$, and the military disruption requirement for JP-5 is 3.3 MBD. The estimated increase in the cost of JP..5 due to the disruption is $\$ 10.67$ per gallon. As shown in Table 2 , the cost increase is, by far, the largest for any region. Contributing to the large cost increase is the reduced processing flexibility during the disruption. Utilization of crude distillation capacity increases 12 percent. Distillate desulfurization is used at full capacity in both scenarios. following:

Table 4 summarizes the impacts of the disruption on the quality of JP-5, including the

Aromatics content increases slightly;

Freezing point decreases (improves) substantially;

Smoke point decreases (degrades) slightly; and

Flash point decreases (degrades) slightly. 


\section{FUEL PRODUCTION IN U.S. BUREAU OF MINES DISTRICT 8 (Texas Gulf Coast)}

The assumed BAU production requirement for JP-5 in BOM 8 is $19.4 \mathrm{MBD}$, and the military disruption requirement for JP-5 is 58.2 MBD. The estimated increase in the cost of JP-5 due to the disruption is $\$ 2.97$ per gallon. As shown in Table 2, the cost increase is the lowest of the three domestic regions, due in part to slightly greater processing flexibility. Utilization of crude distillation capacity decreases 3 percent during the disruption. Table 5 indicates that the disruption has little impact on the quality of JP.5.

The assumed BAU production requirement for $\mathrm{F}-76$ in $\mathrm{BOM} 8$ is $13.2 \mathrm{MBD}$, and the disruption requirement for $\mathrm{F}-76$ is $39.6 \mathrm{MBD}$. The estimated increase in cost for F-76 due to the disruption is $\$ 2.76$ per gallon, relatively low compared to the other regions listed in Table 2. following:

Table 6 summarizes the impacts of the disruption on the quality of F-76, including the

Aromatics content decreases slightly;

Pour point decreases (improves) moderately; and

Flash point increases (improves) substantially.

Because of high percentages of light cycle oils used to produce F-76 during both BAU (46.6 percent) and disruption (44.6 percent), these fuels could have stability problems, with tendencies to produce gums and other particulates. 


\section{FUEL PRODUCTION IN U.S. BUREAU OF MINES DISTRICTS 9 AND 10 (Louisiana, Mississippi, Alabama, and A.rkansas)}

The assumed BAU production requirement for JP-5 in BOMs 9 \& 10 is $4.4 \mathrm{MBD}$, and the military disruption requirement for JP-5 is $13.2 \mathrm{MBD}$. The estimated increase in the cost of JP-5 due to the disruption is $\$ 4.63$ per gallon. As shown in Table 2 , the cost increase is high compared to other regions. Processing inflexibility contributes to the high cost increase. The utilization of crude cistiliation capacity is the same in both scenarios ( 89 percent), and distillate desulfurization is used at full capacity in both scenarios.

In order to produce the required military fuels, civilian diesel fuel specifications had to be relaxed for aromatics (1.0 volume percent above specification) and for sulfur ( 0.025 weight percent above specification). following:

Table 7 summarizes the impacts of the disruption on the quality of JP-5, including the

Aromatics content decreases slightly; and

Smoke point increases (improves) substantially.

The assumed BAU production requirement for F-76 in BOMs 9 \& 10 is $2.2 \mathrm{MBD}$, and the disruption requirement is $6.6 \mathrm{MBD}$. The estimated increase in the cost of F-76 due to the disruption is $\$ 4.51$ per gallon. As shown in Table 2 , the cost increase is the largest for any region.

Table 8 summarizes the impacts of the disruption on the quality of F-76, including the following:

Aromatics content increases moderately;

Cetane index falls (degrades) slightly; and

Pour point decreases (improves) substantially.

Because of high percentages of light cycle oils used to produce F-76 during both BAU (47.1 percent) and disruption (46.1 percent), these fuels could have stability problems, with tendencies to produce gums and other particulates. 


\section{FUEL PRODUCTION IN U.S. BUREAU OF MINES DISTRICT 13 (Alaska, California, Hawaii, Nevada, Oregon, and Washington)}

The assumed BAU production requirement for JP-5 in BOM 13 is $26.9 \mathrm{MBD}$, and the military disruption requirement for JP-5 is 80.7 MBD. The estimated increase in the cost of JP.-5 due to the disruption is $\$ 3.04$ per gallon. As shown in Table 2, the cost increase is relatively low compared to other regions, due in part to greater processing flexibility during the disruption. For example:

Utilization of crude distillation capacity drops 22 percent; and

Utilization of distillate desulfı!i ization capacity drops 4 percent.

As shown in Table 9; the disruption causes a large increase (degradation) of the freezing point of JP-5.

The assumed BAU production requirement for F-76 in BOM 13 is $30.5 \mathrm{MBD}$, and the disruption refuirement for F-76 is $91.5 \mathrm{MBD}$. The estimated increase in the cost of F-76 due to the disruption is $\$ 2.76$ per gallon, relatively low compared to other regions. following:

Table 10 summarizes the impacts of the disruption on the quality of F.76, including the

Aromatics content decreases moderately;

Pour point increases (degrades) substantially; and

Flash point decreases (degrades) substantially.

Because of high percentages of iight cycle oils used to produce F-76 during both BAU ( 46.8 percent) and disruption (51.9 percent), these fuels could have stability problems, with tendencies to produce gums and other particulates. 


\section{FUEL PRODUCTION IN THE ASIA REFINING REGION (Korea, Taiwan, Philippines, and others)}

The assumed BAU production requirement for JP-5 in the Asia refining region is 2.4 $\mathrm{MBD}$, and the military disruption requirement is $7.2 \mathrm{MBD}$. The estimated increase in the cost of JP-5 due to the disruption is $\$ 3.84$ per gallon. As shown in Table 2 , the cost increase is the highest for all foreign regions. Although processing flexibility increases during the disruption, the production share for middle distillates (kerosene and diesel products) is the highest for all foreign regions. Consequently, the value of middle distillate products is high. following:

Table 11 summarizes the impacts of the disruption on the quality of JP-5, including the

Aromatics content decreases slightly; and

Sulfur content decreases slightly.

The assumed BAU production requirement for F-76 in the Asia refining region is 6.4 MBD, and the disruption requirement is $19.2 \mathrm{MBD}$. The estimated increase in the cost of F-76 due to the disruption is $\$ 3.28$ per gallon, the highest for all foreign regions.

Table 12 summarizes the impacts of the disruption on the quality of F-76, including the following:

Aromatics content decreases substantially, due in part to a large decrease in light cycle oils blended to F-76;

Sulfur content decreases substantially;

Cetane index increases (improves) substantially; and

Flash point decreases (degrades) substantially, due in part to naphthas blended to F-76. 


\section{FUEL PRODUCTION IN THE CARIBBEAN REFINING REGION (Puerto Rico, Virgin Islands, Bahamas, Netherlands Antilles, and Trinidad)}

The assumed BAU production requirement for JP-5 in the Caribbean refining region is 2.5 MBD, and the military disruption requirement is $7.5 \mathrm{MBD}$. The estimated increase in the cost of JP-5 due to the disruption is $\$ 2.72$ per gallon. As shown in Table 2 , the cost increase is the lowest for all regions. The low cost increase is due, in part, to the middle distillate production share which is the lowest for all regions. Also contributing to the low cost increase is greater processing flexibility during the disruption. For example,

Utilization of crude distillation capacity drops 6 percent; and

Utilization of distillate desulfurization capacity drops 51 percent.

Table 13 summarizes the impacts of the disruption on the quality of JP-5, including:

Freezing point increases (degrades) slightly; and

Smoke point decreases (degrades) slightly.

The assumed BAU production requirement for F-76 in the Caribbean refining region is 10.1 MBD, and the disruption requirement for F-76 is $30.3 \mathrm{MBD}$. The estimated increase in the cost of F-76 due to the disruption is $\$ 2.63$ per gallon, the lowest increase for all regions. Table 14 summarizes the impacts of the disruption on the quality of F-76, including the following:

Cetane index increases (improves) substantially; and

Pour point decreases (improves) substantially. 


\section{FUEL PRODUCTION IN THE JAPAN REFINING REGION (Japan, including Okinawa)}

The assumed BAU production requirement for JP-5 in the Japan refining region is 0.5 $\mathrm{MBD}$, and the military disruption requirement is $1.5 \mathrm{MBD}$. The estimated increase in cost of JP5 due to the disruption is $\$ 2.95$ per gallon. As shown in Table 2 , the cost increase is relatively low compared to other regions, due in part to greater processing flexibility during the disruption. For example:

Utilization of crude distillation capacity drops 37 percent; and

Utilization of distillate desulfurization capacity drops 14 percent.

The major change in the quality of JP-5, as shown in Table 15 , is an improvement in smoke point.

The assumed BAU production requirement for F-76 in the Japan refining region is 0.8 $\mathrm{MBD}$, and the disruption requirement is $2.4 \mathrm{MBD}$. The estimated increase in cost of F-76 due to the disruption is $\$ 2.81$ per gallon, the median cost increase for all regions. Table 16 summarizes the impacts of the disruption on the quality of F-76, including the following:

Aromatics content increases substantially, due in part to a large increase in light cycle oils blended to F-76;

Pour point decreases (improves) substantially; and

Flash point increases (improves) substantially;

F-76 produced during the disruption contains a large amount (4.3 pereent) of light cycle oils and could tend to form gums and other particulates. 


\section{FUEL PRODUCTION IN THE NORTH EUROPE REFINING REGION (Norway, Sweden, Denmark, Finland, Belgium, Netherlands, Luxembourg, United Kingdom, and Ircland)}

The assumed BAU production requirement for JP-5 in the North Europe refining region is $0.2 \mathrm{MBD}$, and the military disruption requirement for JP-5 is $0.6 \mathrm{MBD}$. The estimated increase in the cost of JP-5 due to the disruption is $\$ 3.10$ per gallon. As shown in Table 2 , the cost increase is relatively modest compared to other regions, due in part to greater processing flexibility during the disruption. For example, utilization of crude distillation capacity drops 32 percent.

Table 17 summarizes the impacts of the disruption on the quality of JP-5. The disruption causes minor quality changes, including a slight improvement in smoke point. 


\section{FUEL PRODUCTION IN THE PACIFIC REFINING REGION (Australia, New Zealand, Indonesia, Singapore, Malaysia, Bahrain, and others)}

The assumed BAU production requirement for JP-5 in the Pacific refining region is 1.6 $\mathrm{MBD}$, and the military disruption requirement is $4.8 \mathrm{MBD}$. The estimated increase in the cost of JP-5 due to the disruption is $\$ 2.85$ per gallon. As shown in Table 2 , the cost increase is among the lowest for all regions, due in part to greater processing flexibility during the disruption. For example:

Utilization of crude distillation capacity drops 46 percent; and

Utilization of distillate desulfurization capacity drops 6 percent.

Table 18 summarizes the impacts of the disruption on the quality of JP-5, including the following:

Smoke point increases (improves) slightly; and

Flash point decreases (degrades) slightly.

The assumed BAU production requirement for F-76 in the Pacific refining region is 18.5 $M B D$, and the disruption requirement is $55.5 \mathrm{MBD}$. The estimated increase in the cost of F.76 due to the disruption is $\$ 2.81$ per gallon, the median cost increase for all regions. following:

Table 19 summarizes the impacts of the disruption on the quality of F-76, including the

Aromatics content decreases substantially, due in part to a large decrease in light cycle oils blended to F-76;

Cetane index increases (improves) substantially;

Pour point decreases (improves) substantially; and

Flash point decreases (degrades) substantially. 


\section{FUEL PRODUCTION IN THE SOUTH EUJROPE REFINING REGION (Spain, Portugal, Italy, Grecce, and Turkey)}

The assumed BAU production requirement for JP-5 in the South Europe refining region is $2.0 \mathrm{MBD}$, and the military disruption requirement is $6.0 \mathrm{MBD}$. The estimated increase in the cost of JP-5 due to the disruption is $\$ 3.19$ per gallon. As shown in Table 2 , the cost increase is relatively modest compared to of ter regions, due in part to greater processing flexibility during the disruption. For example:

Utilization of crude distillation capacity drops 43 percent; and

Utilization of distillate desulfurization capacity drops 44 percent.

Table 20 summarizes the impacts of the disruption on the quality of JP-5, including an increase (improvement) in smoke point.

The assumed BAU production requirement for F-76 in the South Europe refining region is 6.0 MBD, and the disruption requirement is $18.0 \mathrm{MBD}$. The estimated increase in the cost of F-76 due to the disruption is relatively high at $\$ 3.09$ per gallon. Although processing flexibility increases during the disruption, the production share for diesel fuels is the highest for all foreign regions during the disruption. Consequently, the value of diesel fuels is high. following:

Table 21 summarizes the impacts of the disruption on the quality of F-76, including the

Aromatics content increases moderately, due in part to an increase in light cycle oils blended to F-76;

Pour point increases (degrades) substantially; and

Flash point increases (degrades). 


\section{OVERVIEW OF IMPACTS OF MILITARY DISRUPTION}

The Navy Mobility Fuels Forecasting System suggests that the military mobilization will cause a petroleum supply reduction of about 40 pereent of the BAU supply and will create many bottlenecks in the petroleum supply systern.

In order to dse RYM in a feasible mode, relinery operations were analyzed for conditions of impending bottlenecks in the petroleum supply system. Certain conditions of the disruption were relaxed to a point at which petroleum supply could satisfy demand.

The military disruption results in a five-fold increase in the costs of crude oils, which causes a large increase in the costs of production of all refined petroleum products. Regional production cost increases for JP-5 are hetween $\$ 3$ and $\$ 11$ per gallon. For F-76, the production cost increases are between $\$ 3$ and $\$ 5$.

During the disruption, refincry utilization is greatly reduced in most regions, providing in a ased processing flexibility. This flexibility tends to hold down the cost of fuel production.

In BOMs $9 \& 10$ refinery utilization remains high during the disruption, and in BOMs 7 \& 11 refinery utilization increases. Because of processing inflexibility, the cost increases for Navy fuels are particularly high in these regions.

In the Asia refining region, the cost increases for Navy fucls are relatively high during the disruption because of the high production share for middle distillate fuels. Likewise, the eost increase for F-76 in the South Europe refining region is relatively high because of the high production share for diesel fuels.

Navy fuels produced during the disruption are within specifications in all regions. In a number of cases, Navy fuel properties improve during the disruption. However, substantial fuel property degradations occur in the following cases:

BOM 13: F-76 pour point and flash point;

Asia refining region: F-76 flash point;

Japan refining region: F-76 tendency to produce gums and other particulates;

Pacific refining region: F-76 llash point; and

South Europe refining region: F-76 pour point.

Light cycle oils are blended to F-76 at levels exceeding 30) percent in the majority of catses. One explanation for domestic regoons is that F-76 hecomes an attractive disposal option for light cycle oil when the aromatics content of civilian highway diesel fuel is limited to 20 maximum velume percent. 
Light cycle oils have inferior stability, with tendencies to produce gums and other particulates which can cause plugging of diesel engine filters and fouling of fuel injectors. Schrepfer et a ${ }^{36}$ report on studies that have shown rapid degradation in the stability of fuels blended with more than 30 pereent light cycle oil in virgin distillate. Hardy et al ${ }^{37}$ eite the marked instability of a blend of 70 percent good quality F-76 with 30 percent light cycle oil. Because of light cycle oil levels greater than 30 pereent, F-76 instability $;$ roblems are indicated for:

BOMs $1 \& 2$ (BAU and disruption);

BOM 8 (BAU and disruption);

BOMs 9 \& 10 (BAU and disruption);

BOM 13 (BAU and disruption);

Asia refining region (BAU);

Japan refining region (disruption);

Pacific refining region (BAU); and

South Europe refining region (BAU and disruption). 


\section{OBSERVATIONS AND RECOMMENDATIONS}

The Refinery Yield Model of the Navy Mobility Fuels Forecasting System suggests that the severe military disruption could result in large increases in the costs of production of JP-5 and F-76. In most refining regions, refinery processing flexibility increases because of lower crude oil throughput Juring the disruption. Although all Navy fuels produced during the disruption are within specification, there are potentially substantial degradations for certain propertics of $\mathrm{F}-76$ produced in the Pacific basin and in southern Europe.

During both BAU and the disruption, the most prevalent Navy fuel quality problem is F76 instability due to high levels of light cycle oils. It is recommended that the possibility of high percentages of light cycle oils in F-76 be discussed with refiners. These discussions could identify the need for follow-up investigations on the stability and power system impacts of such fuels. 


\section{REFERENCES}

1. P.B. Buck et al, Supply and Distribution of POL to Tactical Forces (U), WSEG Report 204, Institute for Defense Analyses, System Evaluation Division, Arlington, VA, 1973.

2. T. Cutler, "The Military Deniand for Oil," Petroleurn Economist, August 1985, pp. 279-284.

3. T. Cutler, "The Role of Petroleum in Wartime," Petroleum Economist, April 1986, pp. 137 142.

4. T. Cutler, "Vulnerability of Sea Transportation," Petroleum Economist, October 1986, pp. 370-373.

5. T. Cutler, "Strategic Significance of Jet Fuel - Part 1," Petroleum Economist, May 1987, pp. $161-164$.

6. S. Das, G.R. Hadder, P.N. Leiby, R. Lec, and R.M. Davis, Navy Mobility Fuels Forecasting System Phase IV Report, ORNL-6517, Oak Ridgr National Laboratory, Oak Ridge, TN, September 1988.

7. S. Das, R. Lee, R.M. Davis, and G.R. Hadder, "Petroleum Availability in Disrupted Markets," Resources Policy, Vol. 14, September 1988, pp. 173-179.

8. Energy Information Administration, U.S. Department of Energy, International Energy Outlook 1989, DOE/EIA-0484(89), Washington, DC.

9. G.R. Hadder, S. Das, P.N. Leiby, R. Lee, and R.M. Davis, "Navy Fuel Production during a Middle East Political Disruption," Energy, Vol. 14, No. 12, 1989, pp. 965-966.

10. G.R. Hadder, S. Das, R. Lee and R.M. Davis, "Navy Jet Fuel Production: Strategies for a Persian Gulf Crisis," Energy Policy, Vol. 17, No. 3, June 1989, pp. 235-243.

11. G.R. Hadder, S. Das, R. Lee, and R.M. Davis, "Navy Fuel Production during a Military Mobilization Scenario," Energy, Vol. 13, No. 7, 1988, pp. 537-542.

12. P.N. Leiby and R. Lee, Preliminary Results of the SPR Size Cost-Benefit Study, ORNL6563, Oak Ridge National Laboratory, Oak Ridge, TN, 1988.

13. P.E. Mawn, "Allied Peacetime Military Needs," CRA No. 210.01, Memorandum form Paul E. Mawn to Jerry Hadder, Charles River Associates, February 26, 1988.

14. T.R. Curlee, The Impacts of Oil Disturbances: Lessons from Experience, ORNL/TM-8492, Oak Ridgc National Laboratory, Oak Ridgc, TN, 1982. 
15. T.R. Curlee and D.B. Reister, Oil Vulnerability and Intermediate Price Fluctuations: $A$ Preliminary Assessment and Proposal, ORNL/TM-11155, Oak Ridge National Laboratory, Oak Ridge, TN, 1989.

16. G. Horwich and D.L. Weimer, Oil Price Shocks, Market Response, and Contingency Planning, American Enterprise Institute for Public Policy Rescarch, Washington, DC, 1984.

17. G. Horwich and D.L. Weimer, Responding to International Oil Crises, American Enterprise Institute for Public Policy Research, Washington, DC, 1988.

18. U.S. Department of Encrgy, Enengy Security; DOE/S-(0)57, Washington, DC, 1987.

19. T.R. Curlec, A. Turhollow, and S. Das, "Oil Vulnerability and Modeling Methodologies," Energy Economics, Vol. 9, 1988, pp. 3-16.

20. D.B. Reister, $A$ Compact Model of Oil Supply Dismuptionu, ORNL/TM-10519, Oak Ridge National Laboratory, Oak Ridge, TN, 1987.

21. S. Das, R. Lee, and P.N. Leiby, Navy Mobility Fuels Forecasting System Phase VI Report: The Potential Impacts of a Severe Military Conflict on World Petroleum Availability, ORNL66.36, Oak Ridge National Laboratory, Oak Ridge, TN, September 199().

22. System Science Inc., The Oil Market Simulation Model: Model Documentation Report, DOE/EIA/19656-2, Department of Energy, Washington, DC, 1985.

23. A.F. Turhollow, T.R. Curlec, and Sujit Das, Documentation of the Petroleum Allocation (PAL) Mosdel, Oak Ridge National Laboratory, Oak Ridge, TN, March 5, 1987.

24. Refinery Evaluation Modeling System (REMS) Documentation, DOE/EIA-()460), Energy Information Adminisiration, Washington, DC, October 1984.

25. Refinery Evaluation Modeling System (REMS) Documentation, DOE/EIA-()461, Energy Information Administration, Washington, DC, October 1984.

26. Defense Eneryy Information System, DoD 5126.46-M, Department of Defense, Office of the Assistant Secretary of Defense, Manpower, Reserve: Affairs and Logistics, Washington, DC, December 1982.

27. DFAMS Data Element Dictionary, Defense Logistics Agency, Cameron Station, Alcxandria, VA, April 18, 1985.

28. G.R. Hadder, S. Das, R. Lee, N. Domingo, and R.M. Davis, Navy Mobility Fuels Forecasting System Phase V Report: Jet Fuel Conversion by Pacific Fuel Suppliers and Impacts on Nary Fuel Availability, ORNL-6569, Oak Ridge National Laboratory, Oak Ridge, TN, September 1989. 
29. "Army Tests Support NATO Fuel Switch," Oil \& Gas Journal, May 15, 1989, p.26.

30. "EPA to Limit Summertime Gasoline RVP," Oil \& Gas Journal, March 27, 1989, p. 79.

31. Federal Register, Vol. 50, No. 51, March 15, 1985, p. 10606.

32. Federal Register, Vol. 51, No. 124, June 27, 1986, p. 23437.

33. U.S. Refining Industry Capability to Manufacture Ultra Low Sulfur Diesel Fuels, NPRA Survey 1986, National Petroleum Refiners Association, Suite 1000, 1899 L. Street, NW, Washington, DC 20036.

34. G.R. Hadder, S. Das, R. Lee, N. Domingo, and R.M. Davis, Navy Mobility Fuels Forecasting System Phase V Report: Impacts of Ultra Low Sulfur Diesel Fuel Production On Navy Fuel Availability, ORNL-6570, Oak Ridge National Laboratory, Oak Ridge, TN, September 1989.

35. U.S. Petroleum Refining, National Petroleum Council, Committee on U.S. Petroleum Refining, draft working document, National Petroleum Council, 1625 K Street, N.W., Washington, DC, September 26, 1986.

36. M.W. Schrepfer, R.J. Arnold, and C.A. Stansky, "Distillate Stability Ensured by Testing, Treatment," Oil \& Gas Journal, January' 16, 1984, pp. 79-84.

37. D.R. Hardy, R.N. Hazlett, and E.W. White, "Assessment of Storage Stability Additives for Naval Distillate Fuei," Conference Proceedings, 2nd International Conference on Long-Term Storage Stabilities of Liquid Fuels, Southwest Research Institute, San Antonio, TX, July 29 - Augusi 1, 1986, pp. 887-901. 


\section{FIGURE}

ORNL DWG 85-9406R3

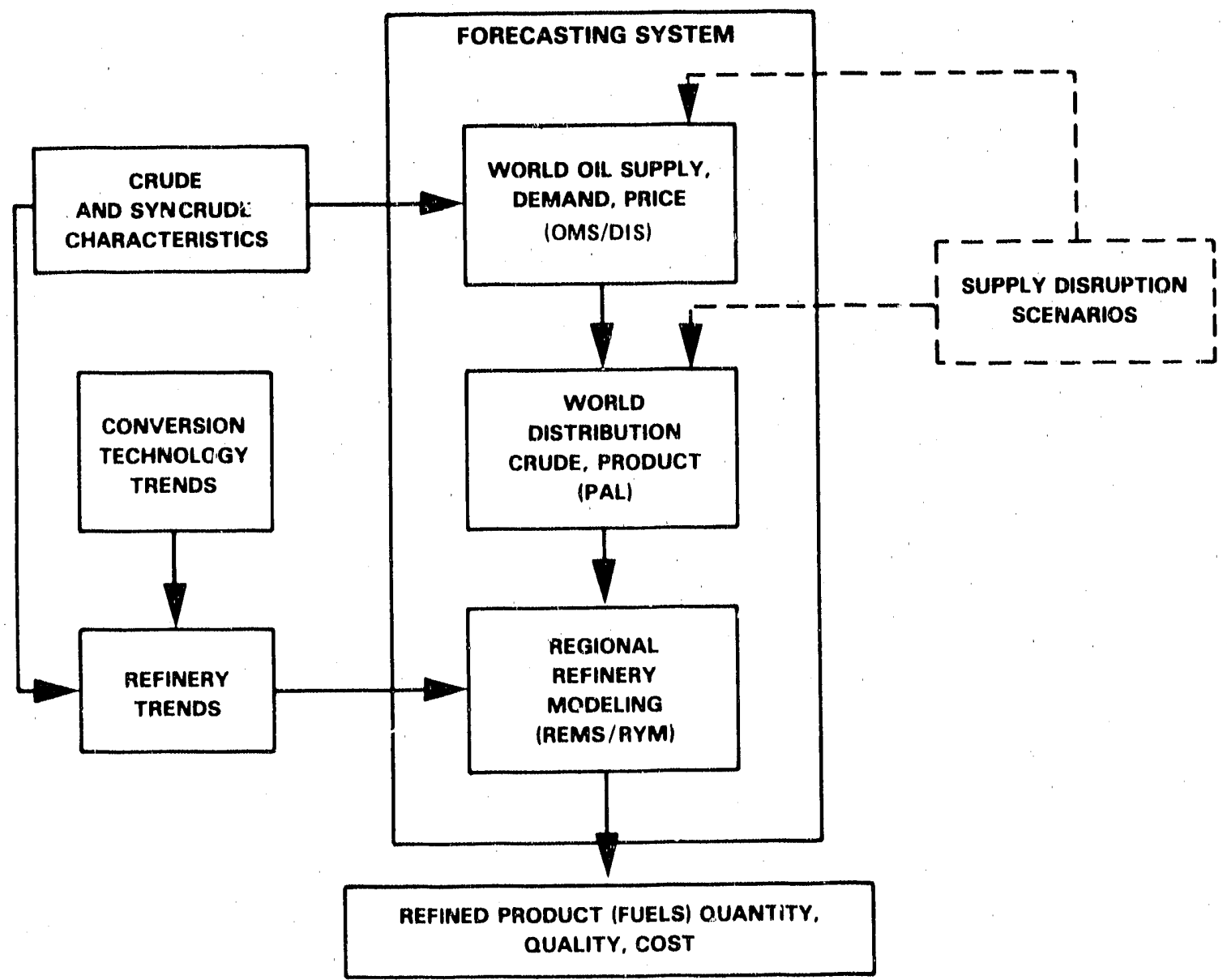

Navy Mobility Fucls Forecasting System and supporting activities. 


\section{TABLES}

For this report, blendstocks are defined as follows:

Diescls - virgin or uncracked stocks with boiling range of 550 to 690 degrees Fahrenheit.

Hydrocracked diescls - products of hydrocracking, with boiling range of 525 to 625 degrees Fahrenheit.

Kerosenes - virgin or uncracked stocks with boiling range of 375 to 550 degrees Fahrenheit.

Light cycle oils - products of fluid catalytic cracking, with boiling range of 430 to 630 degrees Fahrenheit.

Naphthas - virgin stocks with boiling range of 325 to 375 degrees Fahrenheit. 


\begin{tabular}{|c|c|c|}
\hline \multicolumn{3}{|c|}{$\begin{array}{c}\text { Table 1. Assumed Navy ruel production requirements for } \\
\text { business-as-usual } 1995 \text { (MBD) }\end{array}$} \\
\hline Region & $\mathrm{JP}-5$ & $\mathrm{~F}-76$ \\
\hline BOMs $1 \& 2$ & 0.0 & 0.3 \\
\hline BOMs $7 \& 11$ & 1.1 & 0.0 \\
\hline BOM 8 & 19.4 & 13.2 \\
\hline BOMs $9 \& 10$ & 4.4 & 2.2 \\
\hline BOM 13 & 26.9 & 30.5 \\
\hline Asia refining region & 2.4 & 6.4 \\
\hline Caribbean refining region & 2.5 & 10.1 \\
\hline Japan refining region & 0.5 & 0.8 \\
\hline North Europe refining region & 0.2 & 0.0 \\
\hline Pacific refining region & 1.6 & 18.5 \\
\hline South Europe refining region & 2.0 & 6.0 \\
\hline Total & 61.0 & 88.0 \\
\hline
\end{tabular}

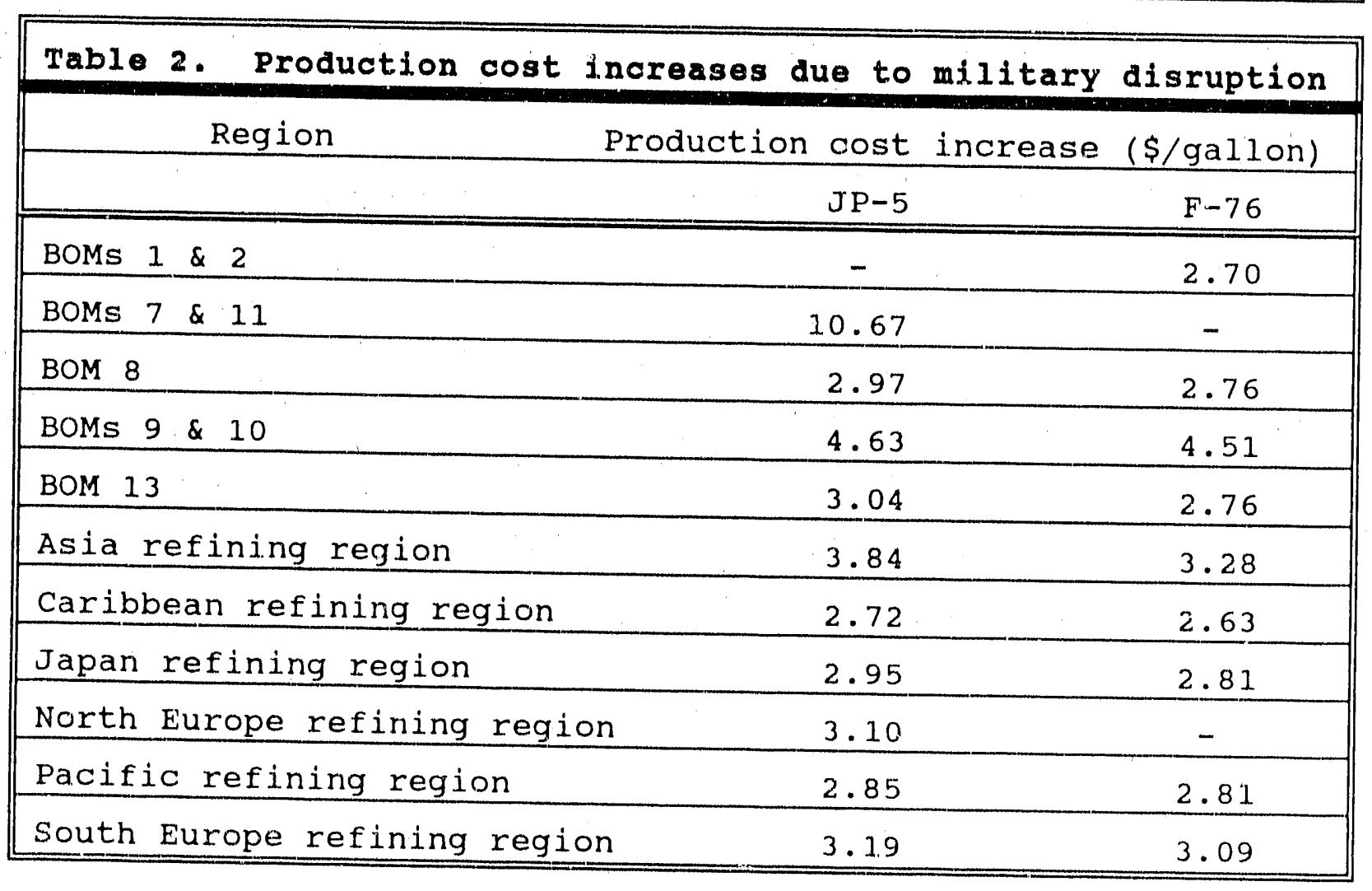




\begin{tabular}{|c|c|}
\hline \multicolumn{2}{|c|}{$\begin{array}{l}\text { Tablo 3. Effects of military disruption on quality of F-76 } \\
\text { produced in BOMs } 122\end{array}$} \\
\hline F-76 Property & Change \\
\hline Aromatics Content (volume percent) & +4.0 \\
\hline sulfur content (weight percent) & 0 \\
\hline API Gravity (degrees) & +0.2 \\
\hline Cetane Index (number) & 0 \\
\hline Pour Point (degrees Fahrenheit) & -43 \\
\hline Flash Point (degrees Fahrenheit) & 0 \\
\hline Kinematic Viscosity (centistokes) & +0.9 \\
\hline 50\% Recovery Temperature (degrees Fahrenheit) & +3 \\
\hline Cracked Blendstocks (volume percent) & -1 \\
\hline
\end{tabular}

\begin{tabular}{||c|c|c|}
\hline \multicolumn{3}{|c|}{ Blendstock Composition } \\
\hline \multicolumn{3}{|c|}{ Volume Percent } \\
\hline Stock & \multicolumn{2}{|c|}{ Volus } \\
\hline Kerosenes & Business-as-usual & Mobilization \\
\hline Diesels & 13.3 & 13.8 \\
\hline Light cycle oils & 40.2 & 40.7 \\
\hline
\end{tabular}




\begin{tabular}{|c|c|}
\hline \multicolumn{2}{|c|}{$\begin{array}{l}\text { Table 4. Effects of military disxuption on quality of JP-5 } \\
\text { produced in Boks } 7 \text { il }\end{array}$} \\
\hline JP-5 Property & Change \\
\hline Aromatics Content (volume percent) & +1.4 \\
\hline Sulfur content (weight percent) & 0 \\
\hline Hydrogen Content (weight percent) & -0.1 \\
\hline API Gravity (degrees) & 0 \\
\hline Freezing Point (degrees Fahrenheit) & -40 \\
\hline Luminometer Number (number) & -2.5 \\
\hline Smoke Point (millimeters) & -0.6 \\
\hline Flash Point (degrees Fahrenheit) & -4 \\
\hline Net Heat of Combustion (BTU/pound) & +10 \\
\hline Kinematic Viscosity (centistokes) & 0 \\
\hline 10\% Recovery Temperature (degrees Fahrenheit) & -4 \\
\hline 50\% Recovery Temperature (degrees Fahrenheit) & +0 \\
\hline 90: Recovery Temperature (degrees Fahrenheit) & -1 \\
\hline Cracked Blendstocks (volume percent) & 0 \\
\hline
\end{tabular}

\begin{tabular}{|c|c|c|}
\hline \multicolumn{2}{|c|}{ Blendstock Composition } \\
\hline & \multicolumn{3}{|c|}{ Volume Percent } \\
\hline Stock & Business-as-usual & Mobilization \\
\hline Kerosenes & 100.0 & 100.0 \\
\hline
\end{tabular}




\begin{tabular}{|c|c|}
\hline \multicolumn{2}{|c|}{$\begin{array}{l}\text { Table 5. Bffects of military disruption on quality of JP-5 } \\
\text { produced in BOM } 8\end{array}$} \\
\hline JP-5 Property & Criange \\
\hline Aromatics Content (volume percent) & 0 \\
\hline Sulfur content (weight percent) & 0 \\
\hline Hydrogen Content (weight percent) & 0 \\
\hline API Gravity (degrees) & 0 \\
\hline Freezing Point (degrees Fahrenheit) & 0 \\
\hline Luminometer Number (number) & $\underline{0}$ \\
\hline Smoke Point (millimeters) & 0 \\
\hline Flash Point (degrees Fahrenheit) & 0 \\
\hline Net Heat of Combustion (BTU/pound) & +16 \\
\hline Kinematic Viscosity (centistokes) & 0 \\
\hline 10\% Recovery Temperature (degrees Fahrenheit) & 0 \\
\hline $50 \%$ Recovery Temperature (degrees Fahrenheit) & 0 \\
\hline 90\% Recovery Temperature (degrees Fahrenheit) & 0 \\
\hline Cracked Blendstocks (volume percent) & 0 \\
\hline
\end{tabular}

\begin{tabular}{||c|c|c|}
\hline \multicolumn{3}{|c||}{ Blendstock Composition } \\
\hline & \multicolumn{3}{|c|}{ Volume Percent } \\
\hline Stock & Business-as-usual & Mobilization \\
\hline Kerosenes & 100.0 & 100.0 \\
\hline
\end{tabular}




\begin{tabular}{|lc||}
\hline Table 6. Effecta of military disuption on quality of F-76 \\
\hline produced in Box 8
\end{tabular}

\begin{tabular}{||l|c|c||}
\hline \multicolumn{3}{|c||}{ Blendstock Composition } \\
\hline \multicolumn{1}{|c|}{ Stock } & \multicolumn{2}{|c||}{ Volume Percent } \\
\hline \hline Kerosenes & Business-as-usual & Mobilization \\
\hline Diesels & 13.2 & 36.4 \\
\hline Light cycle oils & 40.2 & 19.0 \\
\hline
\end{tabular}




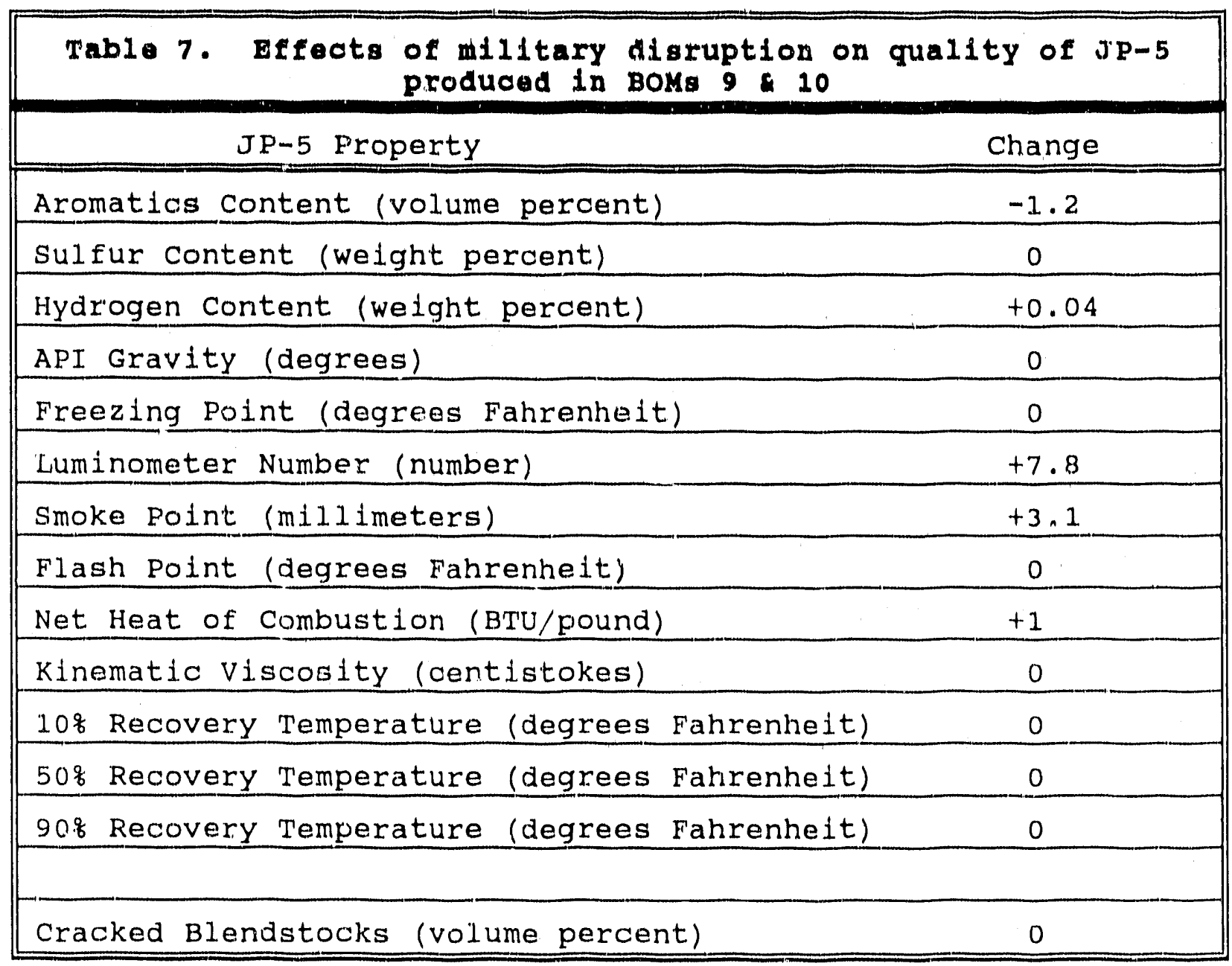

\begin{tabular}{||c|c|c|}
\hline \multicolumn{3}{|c|}{ Blendstock Composition } \\
\hline Stock & \multicolumn{3}{|c|}{ Volume Percent } \\
\hline \hline Kerosenes & Business-as-usual & Mobilization \\
\hline
\end{tabular}




\begin{tabular}{|c|c|}
\hline \multicolumn{2}{|c|}{$\begin{array}{l}\text { Table 8. Effocts of military disruption on quality of } \mathrm{F}-76 \\
\text { produced in BOMs } 9 \text { 10 }\end{array}$} \\
\hline F-76 Property & Change \\
\hline Aromatics Content (volume percent) & +4.9 \\
\hline Silfur Content (weight percent) & +0.1 \\
\hline API Gravity (degrees) & -0.6 \\
\hline Cetane Index (number) & -1 \\
\hline Pour Point (degrees Fahrenheit) & -32 \\
\hline Flash Point (degrees Fahrenhelt) & 0 \\
\hline Kinematic Viscosity (centistokes) & +0.6 \\
\hline 50\% Recovery Temperature (degrees Fahrenheit) & +20 \\
\hline Cracked blendstocks (volume percent) & -1 \\
\hline
\end{tabular}

\begin{tabular}{||c|c|c||}
\hline \multicolumn{3}{|c||}{ Blendstock Composition } \\
\hline & \multicolumn{3}{|c|}{ Volume Percent } \\
\hline Stock & Business-as-usual & Mobilization \\
\hline Kerosenes & 13.1 & 13.5 \\
\hline Diesels & 39.8 & 40.4 \\
\hline Light cycle oils & 47.1 & 46.1 \\
\hline
\end{tabular}




\begin{tabular}{|c|c|}
\hline \multicolumn{2}{|c|}{$\begin{array}{c}\text { Table 9. Efeats of military disruption on quality of Jpm } \\
\text { produced in BoM } 13\end{array}$} \\
\hline JP-5 Property & Change \\
\hline Aromatios content (volume percent) & -0.5 \\
\hline sulfur content (wolght percent) & 0 \\
\hline Hydrogen Content (weight percent) & 0 \\
\hline API Gravity (degrees) & 0 \\
\hline Freezing Polnt (degrees Fahrenheit) & +23 \\
\hline Luminometer Number (number) & 0 \\
\hline Smoke point (miliimeters) & 0 \\
\hline Flash Polnt (degrees Fahrenhelt) & 0 \\
\hline Net Heat of Combustion (BTU/pound) & +1 \\
\hline Kinematic Viscosity (centistokes) & 0 \\
\hline $10 \%$ Recovery Temperature (degrees Fahrenheit) & 0 \\
\hline 50\% Recovery Temperature (degrees Fahrenheit) & 0 \\
\hline 908 Recovery Temperature (degrees Fahrenheit) & 0 \\
\hline Cracked Blendstocks (volume percent) & 0 \\
\hline
\end{tabular}

\begin{tabular}{||c|c|c|}
\hline \multicolumn{3}{|c|}{ Blendstock Composition } \\
\hline & \multicolumn{3}{|c|}{ Volume Percent } \\
\hline Stock & Business-as-usual & Mob111zation \\
\hline \hline Kerosenes & 100.0 & 100.0 \\
\hline
\end{tabular}




\begin{tabular}{|c|c|}
\hline \multicolumn{2}{|c|}{$\begin{array}{c}\text { Table 10. Eftects of military disruption on quality of } \mathrm{F}-76 \\
\text { produoed in Box } 13\end{array}$} \\
\hline F-76 Properti & Change \\
\hline Aromatics Content (volume percent) & -5.2 \\
\hline Sulfur content (weight peroent) & 0 \\
\hline API Gravity (degrees) & +1.3 \\
\hline Cetane Index (number) & 0 \\
\hline Pour point (degrees Fahrenheit) & +11 \\
\hline Flash Point (degrees Fahrenhe1t) & -24 \\
\hline Kinematic Viscosity (centistokes) & 0 \\
\hline 50: Recovery T'emperature (degrees Fahrenheit) & +10 \\
\hline Cracked blendstocks (volume percent) & +5.1 \\
\hline \multicolumn{2}{|l|}{ Blendstock Composition } \\
\hline \multicolumn{2}{|c|}{ Volume Percent } \\
\hline Business-as-usual & Mobilization \\
\hline Kerosenes & 8.6 \\
\hline Diesels & 39.5 \\
\hline Light cycle olis & 51.9 \\
\hline
\end{tabular}




\begin{tabular}{|c|c|}
\hline \multicolumn{2}{|l|}{$\begin{array}{l}\text { Table 11. Effects of m } \\
\text { produced in the Asia re } \\
\text { JP-5 Property }\end{array}$} \\
\hline Aromatics content (volume percent) & $-3 \cdot 7$ \\
\hline Sulfur content (weight percent) & -0.13 \\
\hline Hydrogen Content (weight percent:) & +0.1 \\
\hline API Gravity (degrees) & 0 \\
\hline Freezing point (degrees Fahrenheit) & 0 \\
\hline Luminometer Number (number) & -1.1 \\
\hline Smoke Point (mil1imeters) & -0.4 \\
\hline Flash Point (degrees Fahrenheit) & 0 \\
\hline Net Heat of Combustion (BTU/pound) & +37 \\
\hline Kinematic Viscosity (centistokes) & 0 \\
\hline 10\% Recovery Temperature (degrees Fahrenheit) & 0 \\
\hline 50\% Recovery Temperature (degrees Fahrenheit) & 0 \\
\hline $90 \%$ Recovery Temperature (degrees Fahrenheit) & 0 \\
\hline Cracked Blendstocks (volume percent) & 0 \\
\hline \multicolumn{2}{|l|}{ Blendstock Composition } \\
\hline \multicolumn{2}{|c|}{ Volume Percent } \\
\hline Business-as-usual & Mobilization \\
\hline Kerosenes & 100.0 \\
\hline
\end{tabular}

$\mathrm{T}-11$ 


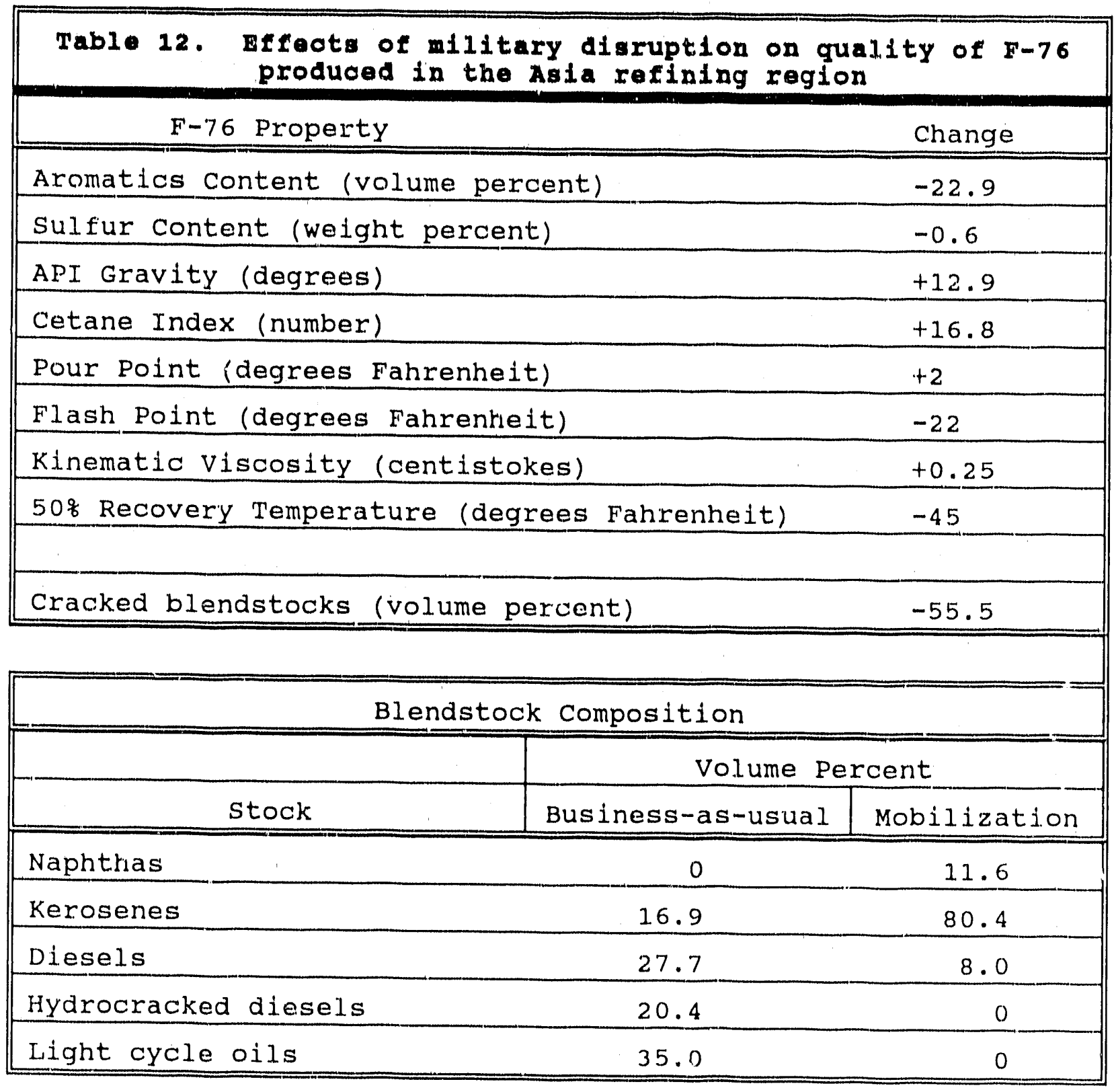




\begin{tabular}{|c|c|}
\hline \multirow{2}{*}{\multicolumn{2}{|c|}{$\begin{array}{l}\text { Table 13. Effects of military disruption on quality of } \mathrm{JP}-5 \\
\text { pxoduced in the caribbean refining region } \\
\text { JP-5 property }\end{array}$}} \\
\hline & \\
\hline Aromatics Content (volume percent) & -0.8 \\
\hline Sulfur Content (weight percent) & 0 \\
\hline Hydrogen Content (weighi percent) & +0.1 \\
\hline API Gravity (degrees) & -0.1 \\
\hline Freezing Point (degrees Fahrenheit) & +2 \\
\hline Luminometer Number (number) & -3.9 \\
\hline Smoke point (millimeters) & -1.5 \\
\hline Flash Point (degrees Fahrenheit) & 0 \\
\hline Net Heat of Combustion (BTU/pound) & +20 \\
\hline Kinematic Viscosity (centistokes) & -0.5 \\
\hline 10\% Recovery Temperature (degrees Fahrenheit) & -2 \\
\hline 50\% Recovery Temperature (degrees Fahrenheit) & +12 \\
\hline 90\% Recovery Temperature (degrees Fahrenheit) & +16 \\
\hline Cracked Blendstocks (volume percent) & 0 \\
\hline \multicolumn{2}{|c|}{ Blendstock Composition } \\
\hline \multicolumn{2}{|c|}{ Volume Percent } \\
\hline Business-as-usual & Mobilization \\
\hline Kerosenes & 100.0 \\
\hline
\end{tabular}




\begin{tabular}{|c|c|}
\hline \multicolumn{2}{|c|}{$\begin{array}{l}\text { Table 14. Effacts of military disxuption on quality of } F-76 \\
\text { produced in the caribbean refining region }\end{array}$} \\
\hline F-76 Property & Change \\
\hline Aromatics content (volume percent) & -0.5 \\
\hline Sulfur content (weight percent) & 0 \\
\hline API Gravity (degrees) & +3.7 \\
\hline Cetane Index (number) & +10.7 \\
\hline Pour point (degrees Fahrenheit) & -24 \\
\hline Flash Point (degrees Fahrenheit) & 0 \\
\hline Kinematic Viscosity (centistokes) & 0 \\
\hline $50 \%$ Recovery Temperature (degrees Fahrenheit) & +39 \\
\hline Cracked blendstocks (volume percent) & +3.5 \\
\hline \multicolumn{2}{|l|}{ Blendstock Composition } \\
\hline \multicolumn{2}{|c|}{ Volume Percent } \\
\hline Business-as-usual & Mobilization \\
\hline Naphthas & 12.7 \\
\hline Kerosenes & 55.2 \\
\hline Diesels & 28.6 \\
\hline Light cycle oils & 3.5 \\
\hline
\end{tabular}




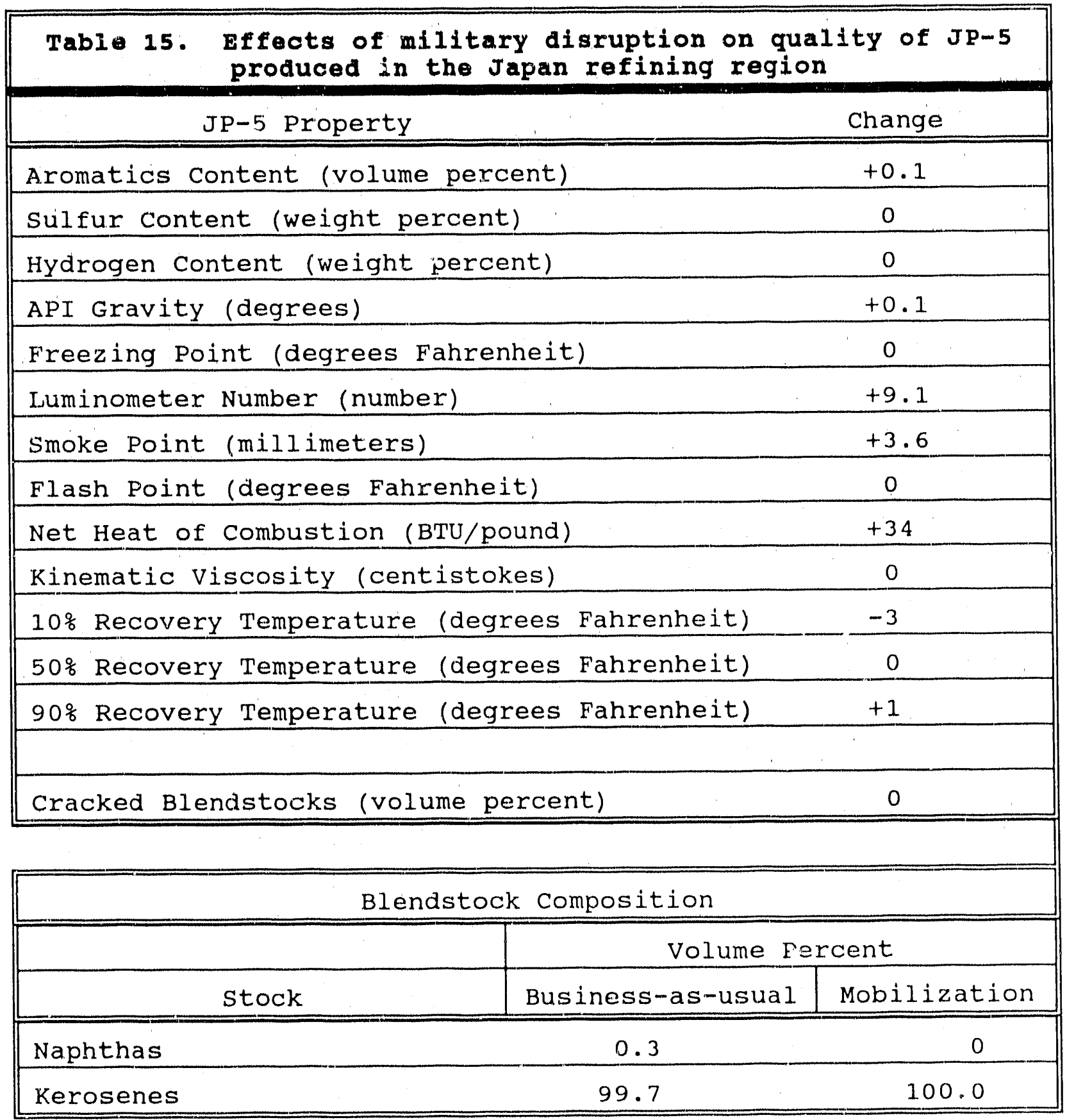




\begin{tabular}{|l|c||}
\hline Table 16. Ef Fects of military disruption on quality of F-76 \\
produced in the Japan refining region
\end{tabular}




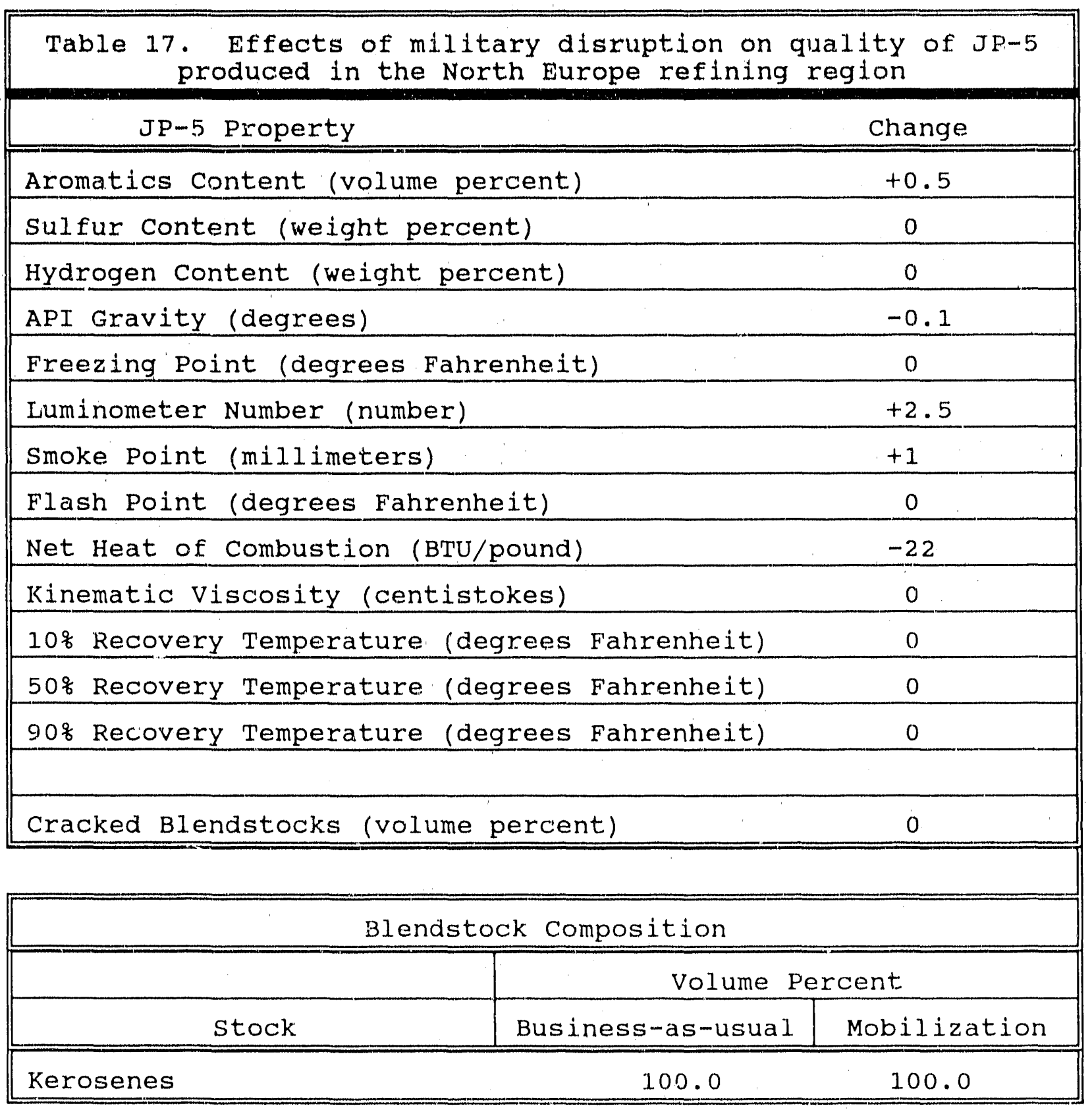




\begin{tabular}{|c|c|}
\hline \multicolumn{2}{|c|}{$\begin{array}{l}\text { Tab1. 18. Effects of military disruption on quality of JP-5 } \\
\text { produced in the pacitio refining region }\end{array}$} \\
\hline JP-5 Property & Change \\
\hline Aromatics Content (volume percent) & +0.2 \\
\hline Sulfur Content (weight percent) & -0.14 \\
\hline Hydrogen Content (weight percent) & 0 \\
\hline API Gravity (degrees) & 0 \\
\hline Freezing Point (degrees Fahrenheit) & 0 \\
\hline Luminometer Number (number) & +2.3 \\
\hline Smoke Point (millimeters) & +1 \\
\hline Flash Point (degrees Fahreriheit) & -4 \\
\hline Net Heat of Combustion (BTU/pound) & +19 \\
\hline Kinematic Viscosity (centistokes) & 0 \\
\hline $10 \%$ Recovery Temperature (degrees Fahrenheit) & -6 \\
\hline $50 \%$ Recovery Temperature (degrees Fahrenheit) & 0 \\
\hline 908 Recovery Temperature (degrees Fahrenheit) & 0 \\
\hline Cracked Blendstocks (volume percent) & 0 \\
\hline
\end{tabular}

\begin{tabular}{||c|c|c|}
\hline \multicolumn{3}{|c||}{ Blendstock Composition } \\
\hline & \multicolumn{3}{|c|}{ Volume Percent } \\
\hline Stock & Business-as-usual & Mobilization \\
\hline Kerosenes & 100.0 & 100.0 \\
\hline
\end{tabular}




\begin{tabular}{|cc||}
\hline Table 19. Effocts of military disruption on quality of F-76 \\
produced in the pacifio refining region
\end{tabular}

\begin{tabular}{||c|c|c||}
\hline \multicolumn{3}{|c||}{ Blendstock Composition } \\
\hline \hline Stock & \multicolumn{3}{|c|}{ Volume Percent } \\
\hline \hline Kerosenes & Business-as-usual & Mobilization \\
\hline Diesels & 17.0 & 67.4 \\
\hline Light cycle oils & 47.7 & 17.6 \\
\hline
\end{tabular}




\begin{tabular}{|c|c|}
\hline \multicolumn{2}{|c|}{$\begin{array}{l}\text { Table 20. Effects of military disruption on quality of Jp-5 } \\
\text { produced in the south vurope refining region }\end{array}$} \\
\hline JP-5 Property & Change \\
\hline Aromatics Content (volume percent) & +0.1 \\
\hline Sulfur content (weight percent) & 0 \\
\hline Hydrogen Content (weight percent) & 0 \\
\hline API Gravity (degrees) & -0.1 \\
\hline Freezing Point (degrees Fahrenheit) & 0 \\
\hline Luminometer Number (number) & +6.8 \\
\hline Smoke Point (millimeters) & +2.7 \\
\hline Flash Point (degrees Fahrenheit) & 0 \\
\hline Net Heat of Combustion (BTU/pound) & -14 \\
\hline Kinematic Viscosity (centistokes) & 0 \\
\hline 10: Recovery Temperature (degrees Fahrenheit) & 0 \\
\hline $50 \%$ Recovery Temperature (degrees Fahrenheit) & 0 \\
\hline $90 \%$ Recovery Temperature (degrees Fahrenheit) & 0 \\
\hline Cracked Blendstocks (volume percent) & 0 \\
\hline
\end{tabular}

\begin{tabular}{||c|c|c|}
\hline \multicolumn{3}{|c||}{ Blendstock Composition } \\
\hline \hline Stock & \multicolumn{3}{|c|}{ Volume Percent } \\
\hline Kerosenes & Business-as-usual & Mobilization \\
\hline
\end{tabular}




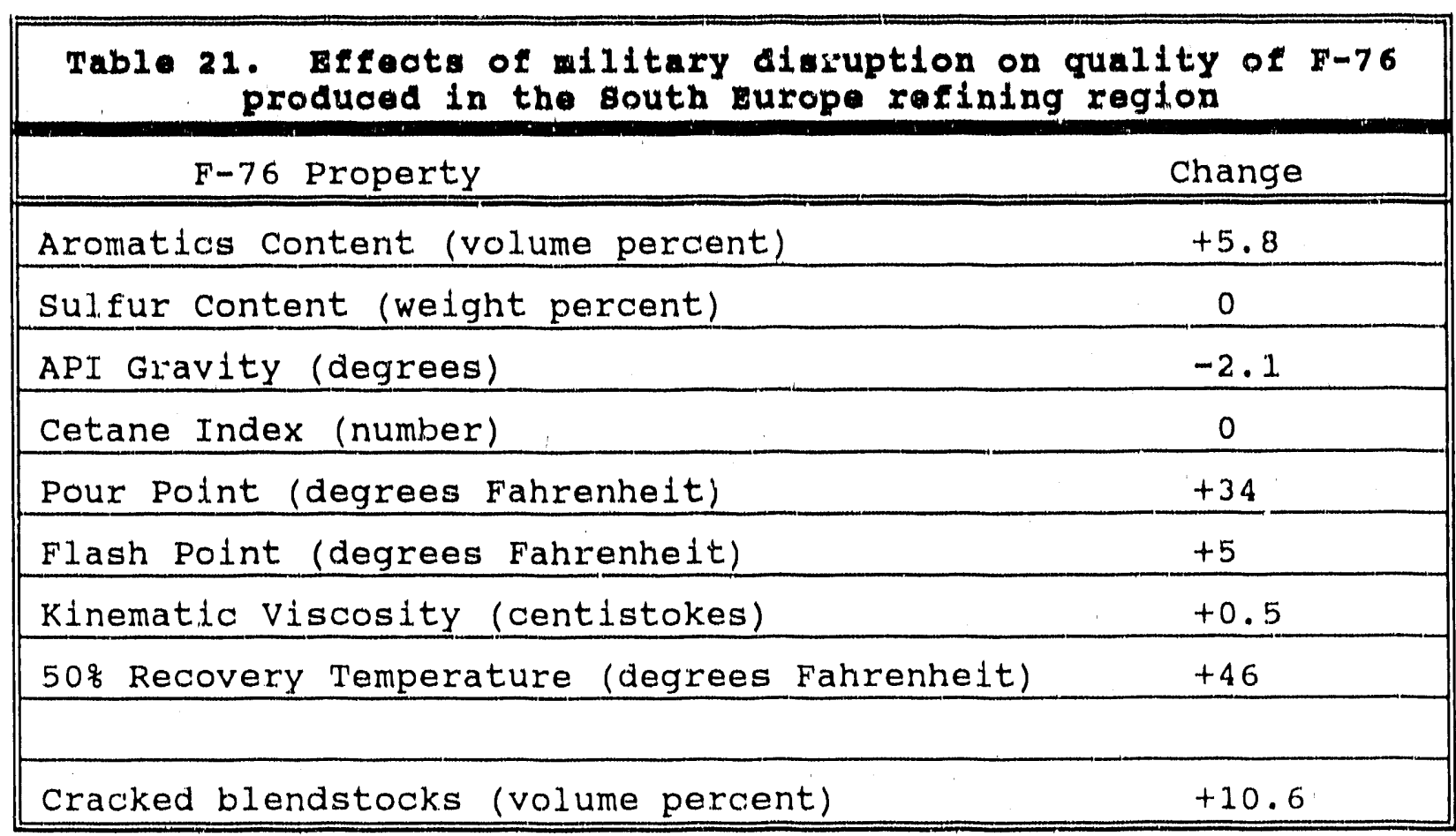

\begin{tabular}{||l|c|c||}
\hline \multicolumn{3}{|c||}{ Blendstock Composition } \\
\hline \multicolumn{1}{|c|}{ Stock } & \multicolumn{3}{|c|}{ Volume Percent } \\
\hline \hline Kerosenes & \multicolumn{3}{|c|}{ Business-as-usual } & Mobilization \\
\hline Diesels & 63.8 & 13.4 \\
\hline Light cycle olls & 0 & 39.8 \\
\hline Hydrocracked diesels & 36.2 & 46.1 \\
\hline
\end{tabular}



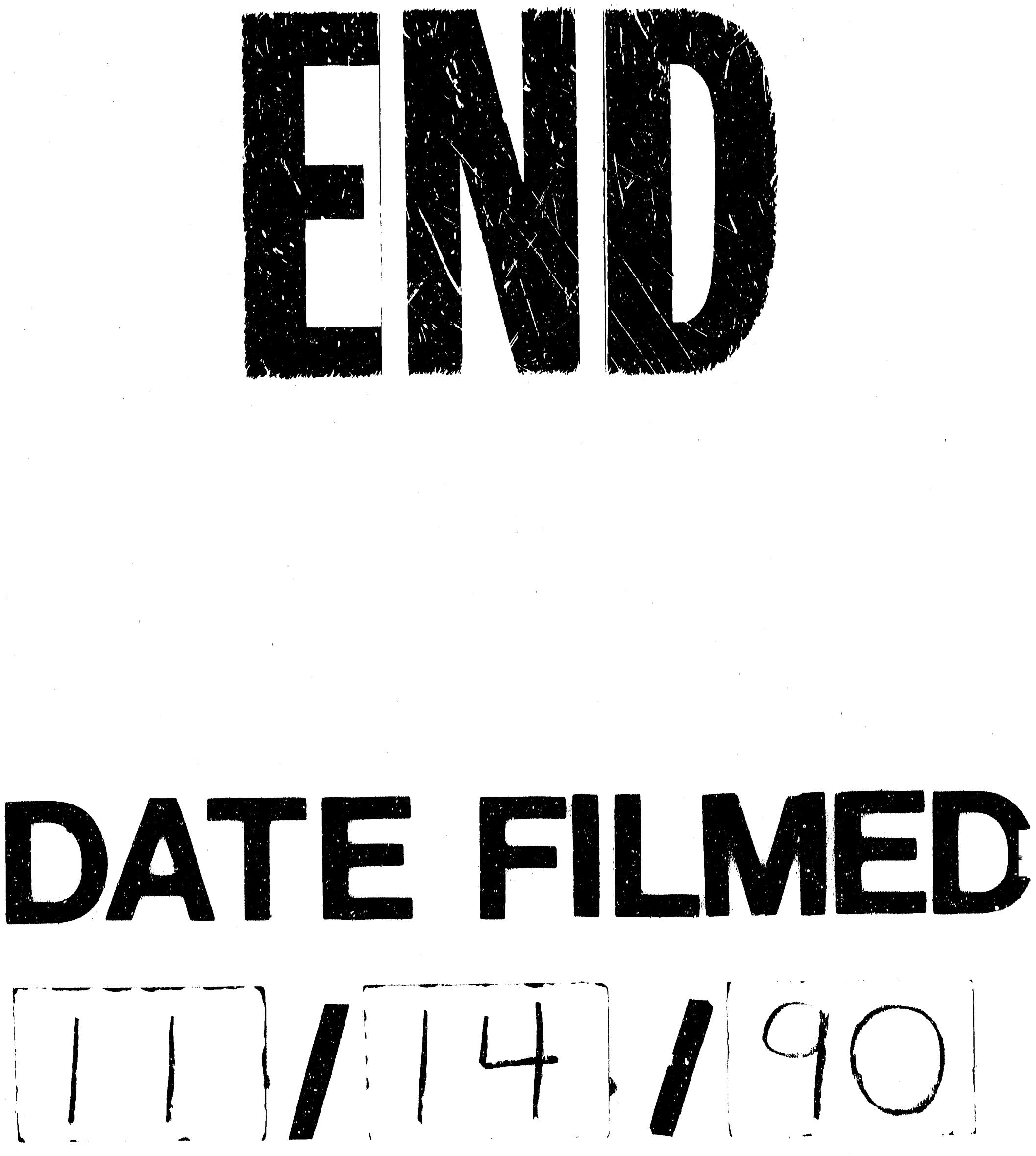
